\title{
Grid Texnologiyalarında İstifadə Olunan Proqram Vasitələrinin Təhlili
}

\author{
Rəşid Oləkbərov ${ }^{1}$, Səməd Dursunov ${ }^{2}$ \\ ${ }^{1,2}$ İnformasiya Texnologiyaları İnstitutu, Bak1, Azərbaycan \\ ${ }^{1}$ t.direktor_muavini@iit.science.az, ${ }^{2}$ samed.dursunov@iit.science.az
}

\begin{abstract}
Xülasə- Məqalədə böyük hesablama resursları tələb edən mürəkkəb məsələlərin həllində istifadə olunan paylanmış hesablama sistemlori təhlil olunmuşdur. Paylanmış hesablama sistemlərində istifadə olunan proqram platformalar haqqında geniş molumat verilmişdir.BOINC proqram platformasının tərkib hissələri analiz olunmușdur.
\end{abstract}

Açar sözlor-Qrid, BOINC, modul, Utility Computing, Distributed Computing, Cluster Computing, Grid Computing

\section{GİRIS}

Müasir dövrdə İnternetə qoşulmuş kompüterlər əsasında yaradılan yüksək məhsuldarlıqlı paylanmış hesablama sisteminə daha perspektivli sistemlər kimi baxılır. Etibarlılığın yüksəlməsi, əlaqə kanallarında məlumatın ötürmə sürətinin artması, informasiya texnologiyaları və şəbəkə avadanlıqlarının sürətli inkişafı şəbəkələrdə cəmlənmiş kompüterlərin hesablama gücünün artmasına gətirib çıxarmışdır. Qeyd etmək lazımdır ki, elmin müxtəlif sahələrində meydana çıxan böyük hesablama və yaddaş resursları tələb edən mürəkkəb məsələlərin həllində fərdi kompüterlərin hesablama gücü kifayət etmir. Göstərilən məsələlərin həllində yüksək hesablama məhsuldarlığına və böyük yaddaşa malik olan superkompüterlərdən geniş istifadə edirlər. Strateji məhsul sayllan superkompüterlərin qiymətlərinin baha olması bir cox ölkələrin onları əldə etməsinə və elmi-texniki tədqiqat işlərində istifadə etməsinə imkan vermir. Bununla yanaşı şəbəkəyə qoşulmuş yüz milyonlarla kompüterlərin hesablama və yaddaş resurslarından səmərəli istifadə olunmur. Aparılan tədqiqatlar göstərir ki, hər bir istifadəçi fərdi kompüterin imkanlarının 25-30\%-dən istifadə edir. Belə olan təqdirdə, fərdi kompüterlərin istifadəsiz qalan hesablama və yaddaş resurslarından mürəkkəb məsələlərin həllində istifadə etmək daha məqsədə uyğun olardı. Yuxarıda qeyd olunanları nəzərə alaraq, dünyada mürəkkəb məsələlərin həllində ucuz başa gələn, az vəsait hesabına yaradılan paylanmış hesablama sistemlərindən genişistifadə olunur [1].

\section{PAYLANMIŞ HESABLAMA SISTEMLORININ YARADILMASI ÜCÜN İSTIFADӘ EDILON TEXNOLOGIYALAR}

Yüksəksürətli əlaqə kanallarının köməyilə verilənlərin emalı mərkəzlərinə (VEM) uzaqdan müraciətin əlyetərli olması istifadəçilər üçün gündəlik fəaliyyətlərində yeni imkanlar yaradır.Bu isə istifadəçilərin informasiyanı əldə etməsi imkanlarının artmasına və eləcə də, hesablama sistemlərinin təşkili prinsiplərinin keyfiyyət dəyişikliyinə səbəb olmuşdur.
Şəbəkə mühitində mürəkkəb məsələlərin həlli üçün paylanmış hesablama sistemlərinin yaradılmasında bir çox texnologiyalardan: Utility Computing, Distributed Computing (paylanmış hesablama), Cluster Computing (klaster texnologiyaları), Grid Computing (Qrid texnologiyaları) və Cloud Computing-dən (bulud texnologiyaları) geniş istifadə olunur [2,3].

Utility Computing - bir kompüterin resurslarının (çoxterminallı emal sistemləri) istifadəçilər arasında paylanması prinsipinə əsaslanır.

Distributed Computing - proqramın alt hissələrinin iki və daha çox kompüterlərdə yerinə yetirilməsi deməkdir. Bu halda, kompüterlərarası əlaqə şəbəkə vasitəsi ilə həyata keçirilir.

Cluster Computing - lokal şəbəkə texnologiyalarının köməyi ilə böyük hesablama və yaddaş resursları tələb edən mürəkkəb məsələnin həllində istifadə olunan və bir təşkilat daxilində yerləşən çoxsaylı hesablama qovşaqlarının (mikroprosessor, kompüter və s.) birləşməsi ilə yaradılan hesablama sistemidir.

Grid Computing - kommunikasiya texnologiyalarının köməyi ilə mürəkkəb məsələlərin həllində istifadə olunan və müxtəlif təşkilatlarda yerləşən çoxsaylı hesablama qovşaqlarının (server, kompüter və s.) birləşməsi ilə yaradılan paylanmış hesablama sistemidir.

Cloud Computing - böyük təşkilatların verilənlərin emal mərkəzlərinin hesablama və yaddaş resurslarından istifadə edərək məsələlərin emal və yadda saxlanmasına xidmət edən hesablama sistemidir.

Utility və Distributed Computing texnologiyalarından keçən əsrin 70-80-ci illərində geniş istifadə olunmuşdur. Kompüterlərarası əlaqə kanallarının sürətinin və etibarlılıq göstəricilərinin aşağı olması bu texnologiyaların geniş tətbiq olunmasına imkan verməmişdir. Keçən əsrin 90-c1 illərindən başlayaraq isə yüksəksürətli əlaqə kanallarının meydana gəlməsi yeni texnologiyaların yaranmasına imkan yaratmışdır. $\mathrm{Bu}$ texnologiyalara misal olaraq Cluster Computing, Grid Computing, Cloud Computing texnologiyalarını göstərmək olar [1].

\section{PAYLANMIŞ HESABLAMA SISTEMLORININ YARADILMASINDA QRID TEXNOLOGIYYALARININ TOTBİQI}

Hal-hazırda dünyada superkompüterlərin yerinə yetirdiyi işləri həyata keçirən və eyni zamanda daha ucuz başa gələn 
virtual superkompüterlərin - qrid sistemlərinin yaradılması üzrə intensiv tədqiqat işləri aparılır [4]. Qrid texnologiyaları kommunikasiya texnologiyalarının köməyi ilə müxtəlif təşkilatlar daxilində yerləşən kompüterlərin istifadəsiz qalan hesablama resurslarından istifadə etməklə yaradılan paylanmış hesablama sistemləridir [5]. Fundamental elmi tədqiqat işlərinin yerinə yetirilməsi zamanı meydana çıxan böyük hesablama və yaddaş resursları tələb edən mürəkkəb məsələlərin həllini həyata keçirən belə sistemlər yüksəksürətli əlaqə kanalına malik olan kompüter şəbəkələri (KŞ) əsasında yaradilır.

"Grid" sözünün ingilis dilindən tərcüməsi "tor" mənasını verir və ilk dəfə 1994-cı ildə amerikalı alimlər Foster və Keselman tərəfindən elmə gətirilmişdir. Bu sistemlərin işləmə mexanizmi analoji olaraq elektrik şəbəkələrindəki gərginlikdən istifadə olunma qaydalarına çox yaxındır. Belə ki, elektrik şəbəkəsindən istifadə zamanı istifadəçi gərginliyin hansı elektrik stansiyasından gəldiyi ilə maraqlanmır. Eləcə də fərdi kompüteri Qrid sisteminə qoşulmuş istifadəçiləri öz məsələlərinin sistemin hansı kompüterlərində həll edildiyini bilmirlər. Onlar məsələnin həlli üçün lazım olan vəsaiti ödəyir və müəyyən vaxtdan sonra nəticəni əldə edirlər $[5,6]$.

Kommunikasiya avadanlıqlarından istifadə etməklə, fərdi kompüterləri bir-birinə qoşub internet şəbəkəsi üzərində virtual verilənlərin emalı mərkəzi (VEM) şəbəkəsi yaratmaq mümkündür.

Qrid sistemlərin yaradılmasında iștirak edən istifadəçilərin fərdi kompüterlərinin hesablama resurslarından ödənişli və ödənişsiz istifadə etmək olar. Ödənişli istifadə edilən kompüterlərin istifadəsiz resurslarının satışa çıxarılması yeni bazar formalaşdırır. Qrid sistemində iştirak edən fərdi kompüterlər özlərinin hesablama gücü haqqında olan məlumatlarını sistemin mərkəzi kompüterinə göndərir və mərkəz də fərdi kompüterdən istifadə etdiyi halda istifadəçiyə buna uyğun haqq ödəyir. Belə bir baza ölkəmizdə hələ formalaşmasa da, artıq dünyanın müxtəlif ölkələrində bu istiqamətdə təcrübələr aparılır. Bu cür sistemlərin yaradılması üçün istifadə edilən əlaqə kanallarında məlumatın ötürülmə sürəti yüksək olmalıdır.

Mürəkkəb hesablama məsələlərini həll etmək üçün KŞdən istifadə edilməsi artıq bu gün tamamilə reallığa çevrilmişdir. $\mathrm{Bu}$ texnologiyaya dünya ölkələri tərəfindən coğrafi cəhətdən səpələnmiş resurslardan istifadə edən paylanmış hesablamaların aparılması üçün daha perspektivli texnologiya kimi baxılır. Hazırda dünyada, KŞ-də olan hesablama resurslarından istifadə üzrə müxtəlif layihələr həyata keçirilir ki, onların da sırasına Distributed.net, SETI@home, World Community Grid (WCG) və s. aid etmək olar. Bu layihələrdə elmin müxtəlif sahələrinə aid (tibb, riyaziyyat, fizika, biologiya və s.) işlər görülür[7].

Qrid texnologiyası əsasında yaradılan sistemin arxitekturası şəkil 1-də göstərilmişdir.

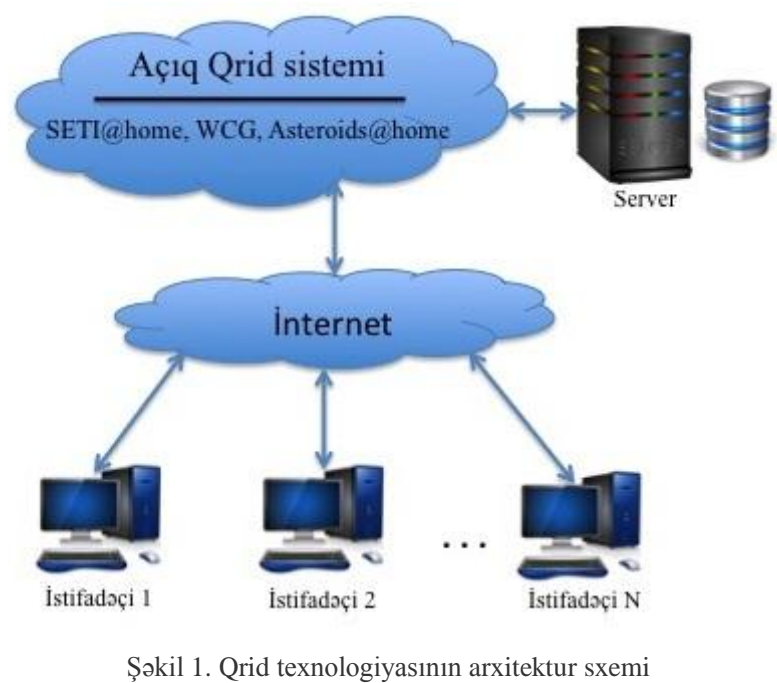

Arxitekturadan göründüyü kimi layihələrdə iştirak edən istifadəçilər internet vasitəsi ilə açıq Qrid sistemlərinə qoşulur.

\section{QRIDD HESABLAMA SISTEMLӘRİ VӘ ARXITEKTURALARI}

Paylanmış emal sistemlərində Qrid texnologiyası əsasında paralel hesablamaları həyata keçirmək üçün aşağıdaki proqram təminatlarından geniş istifadə olunur:

Globus Toolkit - modullar vasitəsi ilə qurulan paylanmış hesablama sistemləridir. Aşağıda göstərilən modullar mövcüddur: resursların ayrılması, komunikasiya, autentifikasiya, verilənlərə giriş, proseslərin yaradılması;

UNICORE - paylanmış hesablamaların qurulmasında istifadə olunan platformadır. UNICORE üçqat arxitektura maliktir. Onlara daxildir: istifadəçi səviyyəsi, UNICORE server və resursları idarə etmə sistemi [8].

BOINC (Berkeley Open Infrastructure for Network Computing - Berklinin şəbəkə hesablamaları üçün açıq platforması) - paylanmış hesablamaların aparılması üçün açıq tipli (GNU LGPL licenziyası altında yayılır) proqram platformasidir.

Hal-hazırda dünyada yuxarıda qeyd olunan platformalardanBOINC proqram platforması daha çox istifadə olunur, buna səbəb bu platformanın qurulmasının və idarə olunmasının daha asan olmasıdır.

BOINC proqram-platforması və arxitekturasına baxaq:BOINC sistemi SETI@home layihəsinin yaradıcısı Devid Andersonun rəhbərlik etdiyi qrup tərəfindən Berkli şəhərində yerləşən Kaliforniya universitetində yaradılmışdır. $\mathrm{Bu}$ sistemin yaradılmasına əsas səbəb radioteleskopdan gələn məlumatların emalı üçün kifayət qədər hesablama gücünün olmaması idi. Ona görə də, sistemi yaradanlar hesablama resurslarını və bir neçə elmi layihələri birləşdirmək qərarına gəliblər. Qeyd olunan bu böyük məsələnin həlli üçün də BOINC proqram platforması yaradılıb. BOINC paylanmış hesablamaların aparılması üçün kliyent-server arxitekturasını istifadə edən bir sistemdir[9].

BOINC proqram-platformasında yaradılan layihələr: 
- SETI@home - yerdən kənar sivilizasiyanın olması üzrə tədqiqatlar aparan "Seti@home.com” layihəsini göstərə bilərik. Layihədə 3,7 mln. fərdi kompüter iştirak edir. İștirakçılar $384 \mathrm{~Kb}$ həcmində ilkin radio astronomik verilənləri qəbul edir. Alınmış verilənlər kompüterdə fon rejimində xüsusi proqramların (Furye çevricisi) köməyi ilə emal edilir;

- World Community Grid (WCG) - layihə çərçivəsində xərçəng, QİÇS (Qazanılmış İmmun Çatışmazlığı Sindromu), grip və s. kimi təhlükəli xəstəliklərin effektiv müalicəsinin tapılması istiqamətində araşdırmalar aparılır;

- Proteins@home - zülalların strukturunun araşdırılması;

- Asteroids@home - fotometrik müşahidələr vasitəsi ilə asteroidlərin forması və firlanma parameterlərinin müəyyən olunmasi.

BOINC proqram platformanın arxitektur sxemi şəkil 2-də göstərilmişdir.

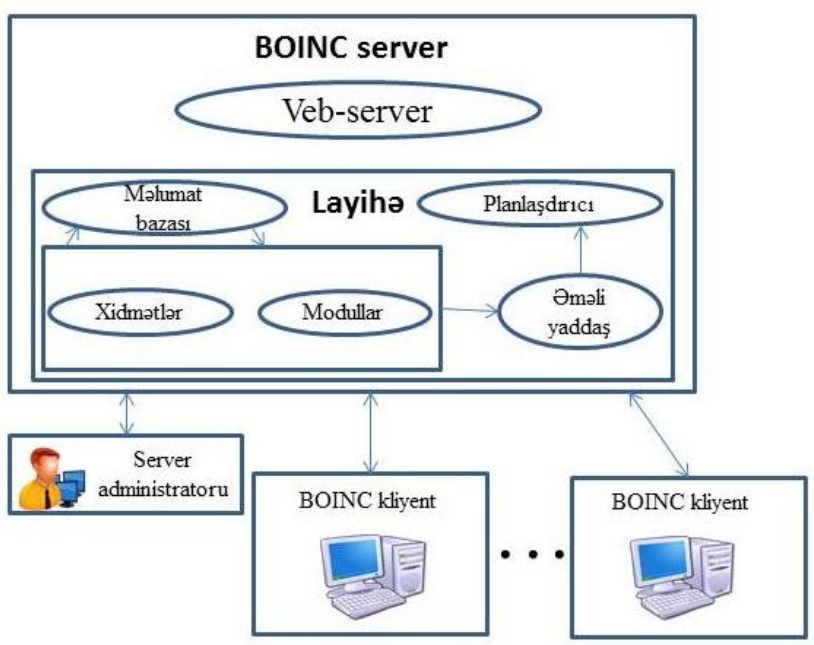

Şəkil 2. BOINC proqram platformasının arxitektur sxemi

BOINC proqram platforması aşağıdaki hissələrdən ibarətdir:

Açıq Qrid sistemlərininidarə olunması əsasən aşağıdakilardan ibarətdir:

- iştirakçıların qeydiyyatı;

- tapşırıqların paylanması;

- emal üçün nəticələrin alınması;

- layhənin verilənlər bazasının idarə olunması.

Proqram platformada istifadə olunan proqram təminatları (modullar) $\mathrm{C}++$ proqramlaşdırma dilində yazılmış proqram destidir.

BOINC proqram platformasının komponentlərinə və tərkib hissələrinə (veb server, verilənlər bazası, proqram modullar) daha ətraflı nəzər salaq[10].

Proqram-platformanin veb serveri.Veb server BOINC serverin vacib hissələrindən biri hesab olunur. $\mathrm{Bu}$ serverin olmağının əsas səbəbi "volunteer computing"-dir - istifadəçılərın diqqətini layihələrə cəlb etməkdir. Bu məqsədlə veb sayt yaradılır, hansı ki layihənin bəşəriyyət üçün nəqədər vacib iş gördüyündən bəhs edir. Odur ki, layihəyə qoşulan iștirakçılar (könülülər) yer kürəsindən kənar sivilizasiyanın tapılmasında (SETI@HOME), yeni dərman preparatların hazırlanmasında (Docking@Home), havanı proqnozlaşdırmada (ClimatePrediction.net) və ya çətin riyazi məsələlərin həllində yaxından iştirak edirlər. Layihə haqqında danışanda, könülüləri cəlb edirik və onlar da potensial hesablama gücü deməkdir. BOINC platformasında olan bütün paylanmış hesablama layihələrı öz iştirakçılarına komandalara birləşmək və toplanan ballarda dəyişməni izləmək imkanı verir.

Proqram platformanın verilənlər bazası.Verilənlər bazası bütün BOINC layihəsinin əsas hissəsidir.

Verilənlər bazasında yerləşir:

- BOINC serverinə aid bütün verilənlər;

- $\quad$ lavələrin versiyaları və verilənləri;

- BOINC kliyent-əlavələrinin verilənləri və versiyalar1;

- qeydiyyatdan keçmiş iştirakçıların və onlara bağlı olan hostlar haqqında molumatlar;

- alt məsələlərin verilənləri və onların hesablamalarının nəticələri[7,8].

Proqram platformada istifadə olunan proqram modulları. Alt məsələlərin vəziyyətini emal edən proqram modulu (Transitioner). Bu xidmət həll olunan alt məsələlərin statusunun və hesablama nəticələrinin emalçısıdır. Bu xidmət əlavələrdən asılı deyil və bütün layihələrə xidmət göstərir. Osas çətinlik ondadır ki, alt məsələlərin bir çox müxtəlif statuslar1 mövcütdur. $\mathrm{Bu}$ statuslar özündə hesablama nəticələrinin vəziyyətini saxlayır. Emal xidməti prosessorları çox yükləyir, bunu nəzərə alaraq xidməti bir nəçə modullara bölmək olar, bu modullar bir və ya bir neçə alt məsələyə cavabdehdir. Bu məsələləri nəzərə alaraq modullar tək bir fiziki serverdə yox, həm də bir neçə serverdə fəaliyyət göstərə bilər.

Nəticələrin yoxlanılmasını təmin edən proqram modulu (Validator).Xidmətin vəzifəsi daxil olan nəticələrin yoxlanılmasını təşkil etməkdir. Alt məsələlərin düz həllini təmin etmək üçün onları bir neçə fərgli kliyent-maşınlarda həll olunur. Nəticəni aldıqda onu yoxlamaq lazımdır: diqər kliyent-maşınlardan gələn cavablarla müqaisə edərək son nəticə təyin olunur.Nəticələri yoxlamaq məqsədilə xidmət məlumat bazasına alınmış yeni nəticələrin qəbulu üçün sorğu göndərir. Yeni nəticələri tapdıqdan sonra, xidmət alınmış nəticəri yoxlamaq üçün xüsusi funksiyanı işə salır. BOINC sistemi vasitəsi ilə həll olunan bütün global məsələlər üçün, yoxlama xidmətində iki funksiya yaratmaq lazımdır. Birinci funksiya iki nəticəni yoxlayır. İkinci funksiya bir neçə kliyentdən göndərilən nəticələrdən ən düzgün nəticənin tapılmasında istifadə olunur. Etalon gərarın alınması üçün lazım olan nəticələrin sayı altməsələ yaradılarkən təyin olunur. Bu sayı həm bütövlüklə proqram-əlavəsi üçün təyin etmək mümkündür, həm dəayrı-ayrı kliyentlər üçün fərqli say təyin edilə bilər. 
Mənimsəməni təmin edən proqram modulu(Assimilator).Mənimsəmə xidmətinin vəzifəsi mütamadi olaraq həl olunmuş məsələlərin mövcudluğunu yoxlamaqdir. Layihənin yaradicısına funksiya yaratmaq lazımdır, hansı ki etalon nəticələrlə nə etmək lazım olduğunu təyin etsin. Məsələn, nəticələri arxivləşdirib və e-poçt vasitə ilə göndərmək mümkündür və ya maraqlı olan fraqmentləri seçib avtomatik olaraq sonrakı verilənlər emalı prosesini işə salmaq olar və onları sənədə yazmaq olar. Alt məsələ mənimsəmə xidməti emal etdikdən sonra bitmiş kimi işarələnir.

Faylların silinməsini təmin edən proqram modulu (File deleter).Fayl silmə xidməti - BOINC layihəsində zibil təmizləyən rolunu oynayır, bu xidmət məsələlərin statusunu yoxlayır, bitmiş və mənimsənmiş altməsələləri axtarır, ondan sonra serverdən həmin altməsələlərə aid daxil olan və çıxan verilənləri silir. Fayılları sildikdə, onlar haqqında yazıları məlumat bazasında saxlamaq imkanı var və istənilən vaxt məlumat bazasından alt məsələ haqqinda məlumat almaq olar.

Ötürməni təmin edən proqram modulu(Feeder).Xidmətdə istifadə edilən proqram təminatının məqsədi həl olunmamış məsələləri yaddaşın xüsusi ayrılmış seqmentinə yükləməkdir, burada etalon nəticəsi alınmamış və məlumat bazasına daxil olunmamış məsələlər nəzərdə tutulur. Belə ilkin işləri server BOINC sisteminin məhsuldarlığını artırmaq məqsədi ilə görür, məlumat bazasına olan müraciətlərin sayını azaldaraq.

Planlayıcı proqram modulu (Scheduler).Planlayıcı - CGIproqramdır, hansı ki, kliyent layihənin serverinəqoşulduqda və məsələnin bir hissəsini tələb etdikdə işə düşür. Məlumat bazasıyla bir başa əlaqə qurmaq yerinə, planlayıcı yaddaşın xüsusi ayrılmış seqmentindən tapşırıqları alır, bu seqmentə tapşırıqlar ötürmə xidməti ilə yüklənilir. Planlayıcı kliyentlərə bir başa özü altməsələ tapşıra bilər, ona görə ki kliyentmaşınları hamısı eyni parameterlərə malik deyil. Məsələn, bir kliyent Mac-versiyanı istifadə edə bilər və yalnız $200 \mathrm{MB}$ yaddaş ayıra bilər və $200 \mathrm{MB}$ əməli yaddaş, diqər kliyent isə Windows-versiyanı istifadə edə bilər və parameterləri daha az olar. Bu zaman planlayıcı Mac-kliyentə daha çox hesablama gücü tələb edən məsələ verir, Windows-kliyentə isə daha az hesablama gücü tələb edən məsələ verir [10].

Paylanmış hesablama sisteminə BOINC proqram platformasının qoşulma ardıcıllığı. BOINC proqram platformasında olan hər hansı bir layihəyə qoşulmaq üçün, ilk öncə layihənin rəsmi veb səhifəsinə daxil olmaq lazımdır. Məsələn,world community grid (WCG)layihəsinə qoşulma ardicılığına baxaq:

- Layihənin veb sahifəsinə daxil oluruq (www.worldcommunitygrid.org) (şəkil 3).

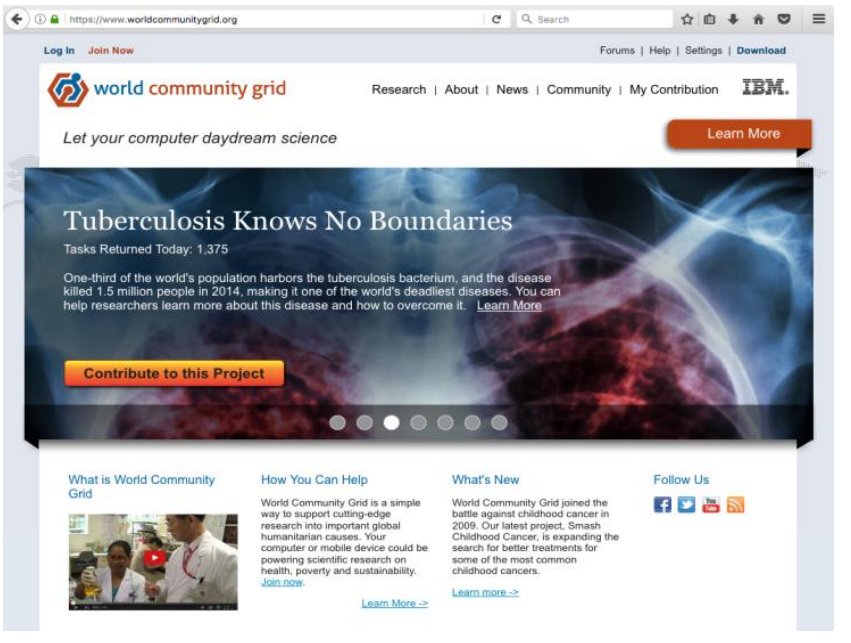

Şəkil 3. WCG layihəsinin veb səhifəsi

- Layihəyə qoşulmaq üçün ilk öncə həmin veb səhifədə qeydiyyatdan keçirik (şəkil 4).

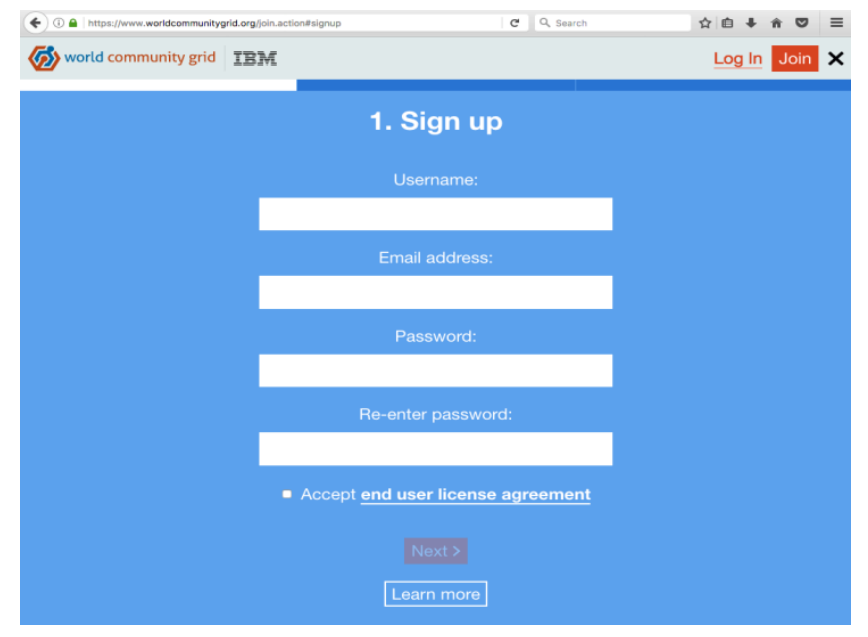

Şəkil 4. WCG veb səhifəsinin qeydiyyat pəncərəsi

- Qeydiyyatdan keçdikdən sonra Download (yükləmə) bölməsinə keçərək BOINC kliyent proqramını hesablamaları aparacağımız maşına yükləyirik(şəkil 5).

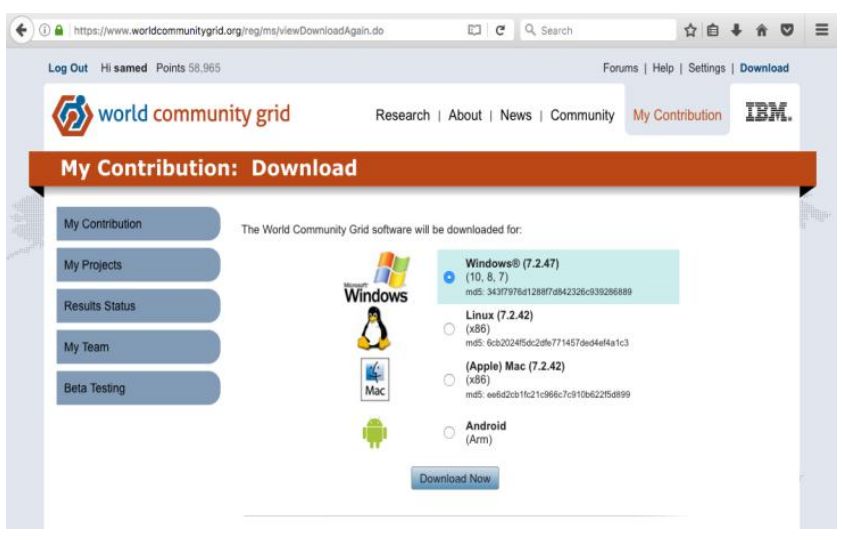

Şəkil 5. WCG veb səhifəsinin yükləmə pəncərəsi

- Kliyent proqramını yükləyib quraşdırandan sonra WCG layihəsini verilən siyahıdan seçərək istifadəçi adı və şifrəni 
daxil edirik və layihəyə qoşuluruq ( şəkil 5). Kliyent proqramında istifadəçi adını və şifrəni daxil etdikdə kliyent proqramı avtomatik olaraq maşınınızın texniki göstəriciləri haqqında məlumatı serverin məlumat bazasına göndərir. Ondan sonra server həmin maşina verəcəyi məsələnin həcmini müəyyənləşdirir(şəkil 6).

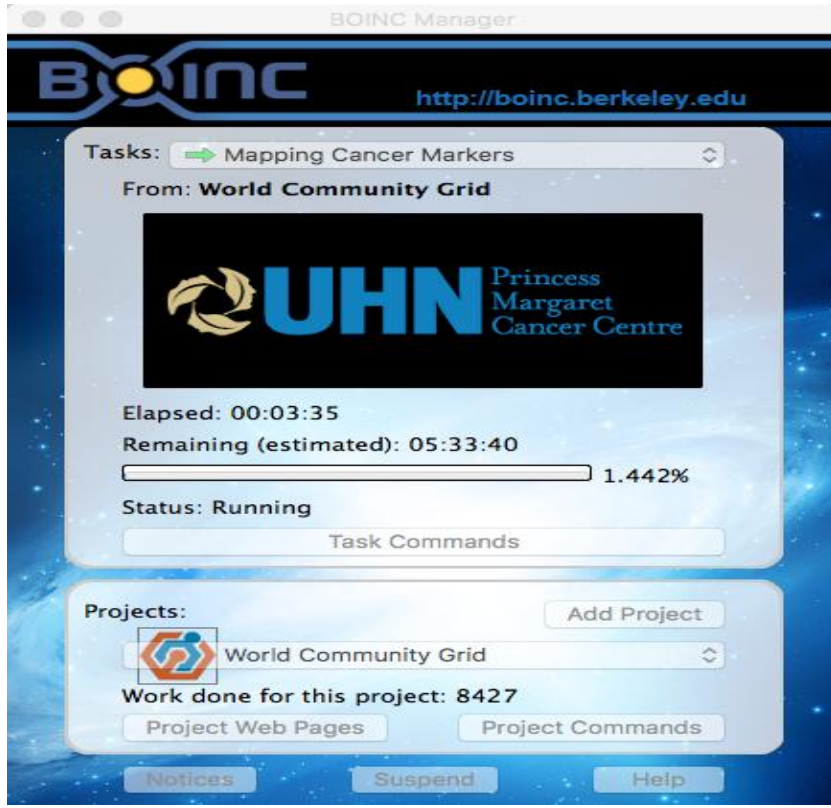

Şəkil 6. BOINC kliyent proqramı

BOINC kliyent-proqramı bir neçə rejimdə işləyir:

- Kompüter işlək vəziyyətdə olarkən sizin ondan istifadə etmədiyiniz zamanlarda;

- Yalnız gecələr kompüter işlək vəziyyətdə olarkən istifadə olunmadiqda;

- Günün istənilən vaxtı kompüterin gücündən az istifadə olduqda[13,14].

\section{NəTIC๐}

Məqalədə paylanmış hesablama sistemlərihaqqında geniş məlumat verilmişdir. Qrid texnologiyasıyası arxitekturası və proqram paltformaları ətraflı araşdırılmışdır. Qrid texnologiyalarında geniş istifadə olunan BOINC proqram platformasının serverinin hissələri və arxitekturasının geniş təhlili və analizi aparılmışdır. Məsələlərin alt məsələlərə bölünməsi və nəticələrin alınması haqqında geniş məlumat verilmişdir. Proqram modulların işləmə prinsipi işləmə ardıcılığına ətraflı baxılmışdır. Böyük hesablama resurları tələb edən məsələlərdə Qrid texnologiyasının istifadəsi çox sərfəli olduğu diqqətə çatdırılmışdır.BOINC proqram platformanın tərkibi və proqram modulları daha ətraflı tədqiq edilmişdir. BOINC sisteminin istifadə ardıcılığ 1 göstərilmişdir.

\section{ӘDӘВİYYAT}

[1] R.Q.Oləkbərov, M.A. Həșimov, Şəbəkə mühitində paylanmış hesablama sisteminin yaradılması texnologiyaları, Ekspressİnformasiya, Bak1, 2015, 74 s.

[2] Л. Черняк «От World Wide Web k World Wide Computer», www.osp.ru/os/2008/07

[3] А.Киселов, В.Корнеев, Р.Семенов, «Управление метакомпьютерными системами», Открытые системы, 2005, №2, c.11-16.

[4] Ю.А.Крюков, «Вычислительная инфраструктура для прикладных задач, будущее и настоящее», Геоинформатика, 2004, №9, с.57-61.

[5] Л. Черняк «Grid как будущее компьютинга», Открытые системы, 2003, №1, c 16-19.

[6] G. Lawton. "Distributed net application create virtual Supercomputers", Computer, 2000, 33, №6, pp.16-20.

[7] R.Q.Oləkbərov, S.M. Dursunov, "Elektron tibdə Qrid texnologiyalarının tətbiqi", "Elektron tibbin multidissiplinar problemləri” I respublika elmi-praktiki konfransı, Bak1, 2016, s. 161163.

[8] https://www.ibm.com/developerworks/ru/library/l-paroshina_toolkits/

[9] https://www.ibm.com/developerworks/ru/library/l-grid/

[10] https://www.ibm.com/developerworks/ru/library/l-boinc/

[11] http://jre.cplire.ru/alt/dec03/4/text.html

[12] https://boinc.berkeley.edu/trac/wiki/ServerIntro

[13] www.worldcommunitygrid.org

[14] https://ru.wikipedia.org/wiki/BOINC

$\mathrm{Bu}$ iş Azarbaycan Respublikasının Prezidenti yanında Elmin Inkişafi Fondunun maliyya yardımı ila yerina yetirilmişdir - Qrant № EIF-2014-9(24)-KETPL-14/02/1 